\title{
Neuroprotection by taurine in ethanol-induced apoptosis in the developing cerebellum
}

\author{
Andrey G Taranukhin ${ }^{1,2^{*}}$, Elena Y Taranukhina ${ }^{1 \dagger}$, Pirjo Saransaari ${ }^{1 \dagger}$, Irina M Podkletnova ${ }^{1 \dagger}$, Markku Pelto-Huikko ${ }^{3 \dagger}$, \\ Simo S Oja ${ }^{1,4+}$ \\ From $17^{\text {th }}$ International Meeting of Taurine \\ Fort Lauderdale, FL, USA. 14-19 December 2009
}

\begin{abstract}
Background: Acute ethanol administration leads to massive apoptotic neurodegeneration in the developing central nervous system. We studied whether taurine is neuroprotective in ethanol-induced apoptosis in the mouse cerebellum during the postnatal period.

Methods: The mice were divided into three groups: ethanol-treated, ethanol+taurine-treated and controls. Ethanol (20\% solution) was administered subcutaneously at a total dose of $5 \mathrm{~g} / \mathrm{kg}(2.5 \mathrm{~g} / \mathrm{kg}$ at time $1 \mathrm{~h}$ and $2.5 \mathrm{~g} / \mathrm{kg}$ at 3 h) to the ethanol and ethanol+taurine groups. The ethanol+taurine group also received two injections of taurine $(1 \mathrm{~g} / \mathrm{kg}$ each, at time zero and at $4 \mathrm{~h})$. To estimate apoptosis, immunostaining for activated caspase-3 and TUNEL staining were made in the mid-sagittal sections containing lobules I-X of the cerebellar vermis at 12 or 8 hours after the first taurine injection. Changes in the blood taurine level were monitored at each hour by reverse-phase high-performance liquid chromatography (HPLC).

Results: Ethanol administration induced apoptosis of Purkinje cells on P4 in all cerebellar lobules, most extensively in lobules IX and $X$, and on P7 increased the number of activated caspase-3-immunoreactive and TUNEL-positive cells in the internal layer of the cerebellum. Administration of taurine significantly decreased the number of activated caspase-3-immunoreactive and TUNEL-positive cells in the internal layer of the cerebellum on P7, but had no effect on Purkinje cells in P4 mice. The high initial taurine concentration in blood of the ethanol+taurine group diminished dramatically during the experiment, not being different at $13 \mathrm{~h}$ from that in the controls.

Conclusions: We conclude that the neuroprotective action of taurine is not straightforward and seems to be different in different types of neurons and/or requires prolonged maintenance of the high taurine concentration in blood plasma.
\end{abstract}

\section{Background}

A moderate alcohol intake may not be harmful and has even beneficial effects in prevention of cardiovascular diseases, for example [1]. On the other hand, heavy alcohol consumption is associated with the reduced brain mass, neuronal loss, neuropathological changes and results in the impairment of cognitive functions, amnesia, dementia and even a significant increase in

\footnotetext{
* Correspondence: andrey.taranukhin@uta.fi

† Contributed equally

'Brain Research Center, University of Tampere Medical School, Tampere, Finland

Full list of author information is available at the end of the article
}

mortality [2-4]. In adult rats a short-term increase in the blood ethanol concentration up to $6 \mathrm{~g} / \mathrm{l}$ has not been toxic to the central nervous system [5]. However, in the developing nervous system the situation is quite different. The blood ethanol concentration above $0.5 \mathrm{~g} / \mathrm{l}$ in mice during their early postnatal life induces mild apoptotic neurodegeneration [6], which becomes dosedependently more severe from the concentration of $2 \mathrm{~g} /$ 1 upward [7].Intrauterine exposure of the human fetus to ethanol due heavy drinking or repeated binge drinking of pregnant women causes a wide spectrum of developmental disorders known as the fetal alcohol syndrome $[8,9]$. The human fetal brain is particularly

\section{() Biomed Central}


sensitive to the adverse effects of alcohol during the last trimester of pregnancy, the period of synaptogenesis, also known as the brain growth spurt period. In rodents, the same period of increased sensibility to ethanol is during the early postnatal period [10]. It has been well documented that acute ethanol exposure to neonatal mice induces neuronal loss by apoptosis [6,7,11-14]. Prevention of ethanol-induced apoptosis can save a huge amount of neurons and significantly decrease the harmful consequences of alcohol intoxication.

Taurine is a simple sulphur-containing free amino acid abounding in electrically excitable tissues such as brain, retina, heart and skeletal muscles [15]. It is involved in a wide range of physiological processes, for example, in osmoregulation, lipid metabolism, intracellular calcium regulation, neuronal development, neuromodulation and cell protection [16-20]. Recent findings also imply taurine in apoptosis regulation [21-24]. In the present work we focused on the possible protection of Purkinje cells and neurons in the internal layer of the developing cerebellum against apoptosis induced by acute ethanol administration. Among possible means to prevent pathological apoptosis taurine is very attractive since it is a naturally-occurring and non-toxic compound.

\section{Methods}

\section{Animals and treatments}

Adult NMRI mice for breeding were purchased from Harlan, Netherlands. Four (P4) - and seven (P7) - day old infant male mice were used in the experiments (day of birth is day 0 ). The experiments on animals were carried out in accordance with the European Community Council Directive 86/609/EEC. All efforts were made to reduce their number and suffering. The mice in each litter were divided into three groups: ethanoltreated, ethanol+taurine-treated and controls. To induce acute alcohol intoxication ethanol was mixed in sterile saline to a $20 \%$ solution and administered subcutaneously at a total dose of $5 \mathrm{~g} / \mathrm{kg}(2.5 \mathrm{~g} / \mathrm{kg}$ at time $1 \mathrm{~h}$ and $2.5 \mathrm{~g} / \mathrm{kg}$ again at $3 \mathrm{~h}$ ) to the ethanol and ethanol+ taurine groups. This dosing regimen was well documented to produce an elevation in the blood alcohol concentration above $2 \mathrm{~g} / \mathrm{l}$ for at least 8 hours and led to significant and widespread apoptotic neurodegeneration in the developing brain [7] and cerebellum [25]. The ethanol+taurine group also received two injections of taurine $(1 \mathrm{~g} / \mathrm{kg}$ diluted with saline). The first taurine injection was given one hour before the first ethanol injection and the second one hour after the second ethanol injection. The control animals were given saline subcutaneously. Twelve (P4) and eight hours (P7) after the first ethanol injection the mice were killed by decapitation. Blood samples from each animal were collected separately in lithium-heparin tubes and centrifuged at $1750 \mathrm{rpm}$ for $10 \mathrm{~min}$ to obtain plasma. The samples were frozen until HPLC analyses. The cerebella were rapidly excised and fixed in $4 \%$ paraformaldehyde in phosphate buffered saline for at least 3 days at $4^{\circ} \mathrm{C}$. They were after the routine histological processing embedded in paraffin and cut with a microtome into $5-\mu \mathrm{m}$ thick mid-sagittal sections containing lobules I-X of the cerebellar vermis.

\section{High Performance Liquid Chromatography (HPLC)}

The concentration of taurine in the blood serum was measured using HPLC with fluorescent detection after precolumn derivatization with o-phthaldialdehyde (OPA) using the analysis equipment system of Shimadzu Scientific Instruments (Kyoto, Japan). The separation column was 4.6 x $250 \mathrm{~mm}$ Ultropac 8 Resin, lithium form (Farmacia, Denmark). Derivatization of taurine was performed with the OPA reagent $(0.2 \%$ OPA, $0.1 \%$ mercaptoethanol and $1 \%$ ethanol in $1 \mathrm{M}$ borate buffer, $\mathrm{pH}$ 10.4). The elution was done with lithium citrate buffers in the following order: (1) $0.2 \mathrm{M}, \mathrm{pH} 2.80$, (2) 0.3 $\mathrm{M}, \mathrm{pH} 3.00$, (3) $0.5 \mathrm{M}, \mathrm{pH} 3.15$, (4) $0.9 \mathrm{M}, \mathrm{pH} 3.50$, and (5) $1.6 \mathrm{M}, \mathrm{pH}$ 3.30. Fluorescence of taurine derivatives was measured with an RF-10A detector using the excitation and emission wavelengths set at $340 \mathrm{~nm}$ and 450 $\mathrm{nm}$, respectively. The concentrations of taurine were finally estimated using a commercial amino acid mixture (Pickering, UK) as an external standard and diamino-nbutyrate as an internal standard.

\section{Immunohistochemistry}

The sections were deparaffinized with xylene and hydrated in a graded ethanol series to distilled water. After antigen retrieval by microwave $[20 \mathrm{~min}$ at $1000 \mathrm{~W}$ in $0.01 \mathrm{M}$ citrate buffer ( $\mathrm{pH}$ 6.0)], washing in phosphate buffered saline and blocking with $0.5 \%$ hydrogen peroxide in this buffer for $20 \mathrm{~min}$, the specimens were preincubated for $30 \mathrm{~min}$ in serum-blocking solution $(1 \%$ bovine serum albumin and $0.3 \%$ Triton X-100 in the above buffer). The specimens were thereafter incubated with polyclonal activated caspase- 3 antibody [cleaved caspase-3 (Asp 175) antibody, Cell Signaling Technology Inc., diluted 1:200 in serum-blocking solution] in moist chambers overnight at $4^{\circ} \mathrm{C}$. After incubation with the primary antibody, the sections were incubated with biotinylated secondary antibody (goat anti-rabbit 1:500 in blocking solution) and $\mathrm{ABC}$ complex (Vectastain Elite $A B C$ Kit, Vector Laboratories, Inc.), each for $30 \mathrm{~min}$. Diaminobenzidine was used as a chromogen to visualize the sites expressing activated caspase- 3 immunoreactivity. The sections for negative control were incubated without the primary antibodies to rule out nonspecific staining. Finally, the sections were counterstained by 
hematoxylin-eosin to better reveal histological details, dehydrated and mounted.

\section{Detection of cell death in situ}

DNA fragmentation is one of the most precise markers by which apoptotic cells are recognized. In order to detect DNA fragmentation of cell nuclei, terminal deoxynucleotidyl transferase-mediated dUTP nick end-labeling (TUNEL) reaction was applied to the paraffin sections using the In Situ Cell Death Detection Kit, POD (Roche Applied Science, Germany). After deparaffinization, the sections were irradiated with microwaves in $0.01 \mathrm{M}$ citric acid buffer (pH 6) for $10 \mathrm{~min}$ at $750 \mathrm{~W}$. No inhibition of endogenous peroxidase was performed because $\mathrm{H}_{2} \mathrm{O}_{2}$ weakens terminal deoxynucleotidyl transferase activity [26] and induces DNA breaks [27]. Sections were incubated with the TUNEL reaction mixture for $60 \mathrm{~min}$ at $37^{\circ} \mathrm{C}$. Further incubation with peroxidaseconjugated antibody was performed for $30 \mathrm{~min}$ at $37^{\circ} \mathrm{C}$. The sections were stained with diaminobenzidine for 10 min at the room temperature and then counterstained with hematoxylin-eosin.

\section{Image analysis and cell counting}

The sections were processed in parallel under standardized conditions for immunostaining or TUNEL to minimize variability in labeling conditions. An image analysis system comprising of an IBM PC, Nikon Microphot-FXA microscope, SensiCam digital camera (PCO Computer Optics $\mathrm{GmbH}$ ), Image-Pro Plus (Media Cybernetics) was used for analysis of caspase- 3 immunoreactivity and TUNEL-staining in the histological sections of the cerebellum. At least five sections cut at the same level of the cerebellar vermis from every animal were analyzed. The amount of cells labeled for active caspase-3 or TUNEL were calculated in every slice in each lobule and the area of each lobule was also measured. The data are presented as the average number of labelled cells per $\mathrm{mm}^{2}$ for each experimental group.

\section{Statistical analysis}

One-way analysis of variance (ANOVA) was used to compare the number of activated caspase-3-immunoreactive cells and TUNEL-positive cells among the experimental groups. When ANOVA showed a significant difference, the post hoc Bonferroni test was applied to demonstrate the difference. Each value is expressed as mean \pm standard deviation. Differences were considered significant when the calculated $p$ value was $<0.05$.

\section{Results}

In the present work we focused on the Purkinje cells and neurons in the internal granular cell layer of the cerebellum. The Purkinje cells were identified by their size, shape and specific localization in the cerebellar lobules. Because we did not make specific labeling to identify different types of neurons and glial cells in the internal granular cell layer of the cerebellum, we refer to these cells as internal granular layer (IGL) cells. We studied the possible protective effect of taurine against ethanol-induced apoptosis in the Purkinje cells on P4 and the IGL cells on P7 mice because of the extremely high sensitivity of these cell types at these ages to ethanol-induced apoptotic neurodegeneration.

Effects of taurine on ethanol-induced caspase- 3 activation Activated caspase-3-immunoreactive (IR) cells in the IGL found in each cerebellar lobule in the saline-treated control mice on P7 evidences physiological cell death which normally occurs at this period of development (Figure 1A, 1D; Figure 2A, 2D; Figure 3A, 3D). Only a few activated caspase-3-IR Purkinje cells were found in the saline-treated control mice on P4.

In the ethanol-treated pups on P4 a large number of activated caspase-3-IR Purkinje cells were discernible in all lobules with the highest amount in lobules IX and X (Figure 4B, 4E). In lobules I-II, III, IV-V, VI-VII and VIII the number of capase-3-IR Purkinje cells was also significantly increased when compared to the control group (Figure 5A). On P7 ethanol administration induced very little response to caspase- 3 activation in the Purkinje cell layer which hardly differed from the control group. However, ethanol treatment on P7 induced widespread activation of caspase- 3 in the IGL (Figure 1B, 1E; Figure 2B, 2E; Figure 3B, 3E). The amount of activated caspase-3-IR IGL cells in each lobule was markedly greater than in the saline-treated pups (Figure 5C). The highest immunoreactivity for activated caspase- 3 was found in I-II, III and IV-V vermian lobules.

In the ethanol+taurine-treated group on P4 the number of activated caspase-3-IR Purkinje cells in each lobule was approximately the same as in the pups treated only with ethanol and significantly higher than in the saline-treated control group (Figure 4; Figure 5A). However, in contrast to the Purkinje cells at age P4, taurine treatment significantly decreased the number of activated caspase-3-IR cells in the IGL on P7 in each lobule (Figure 1C, 1F; Figure 2C, 2F; Figure 3C, 3F; Figure $5 \mathrm{C}$ ). The amount of rescued cells from caspase- 3 activation were different in different lobules and varied from $34 \%$ to $41 \%$ for lobules VI, VII and X, and from $45 \%$ to $57 \%$ for lobules I-II, III, IV-V, VIII and IX.

\section{Effects of taurine on ethanol-induced DNA fragmentation}

A few TUNEL-positive cells in the Purkinje cell layer on P4 and in the IGL on P7 were detected in the salinetreated control groups showing physiological cell death 

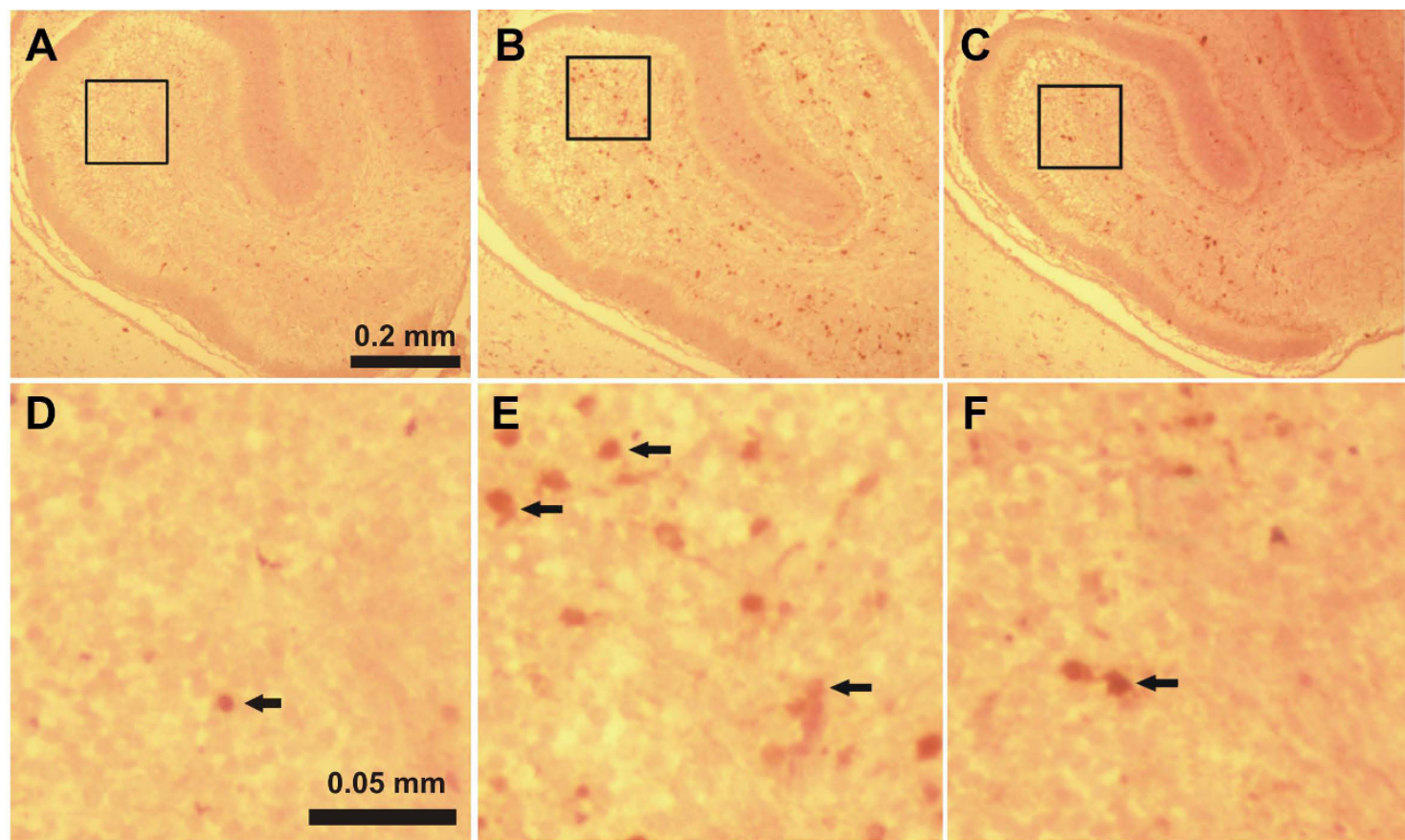

Figure 1 Immunostaining for activated caspase-3 in lobule II of the cerebellum of 7-day-old mice 8 hours after the first ethanol injection A, D: control group, B, E: ethanol-treated group, C, F: ethanol+taurine-treated group. The activated caspase-3-immunoreactive cells in the IGL are indicated by black arrows.
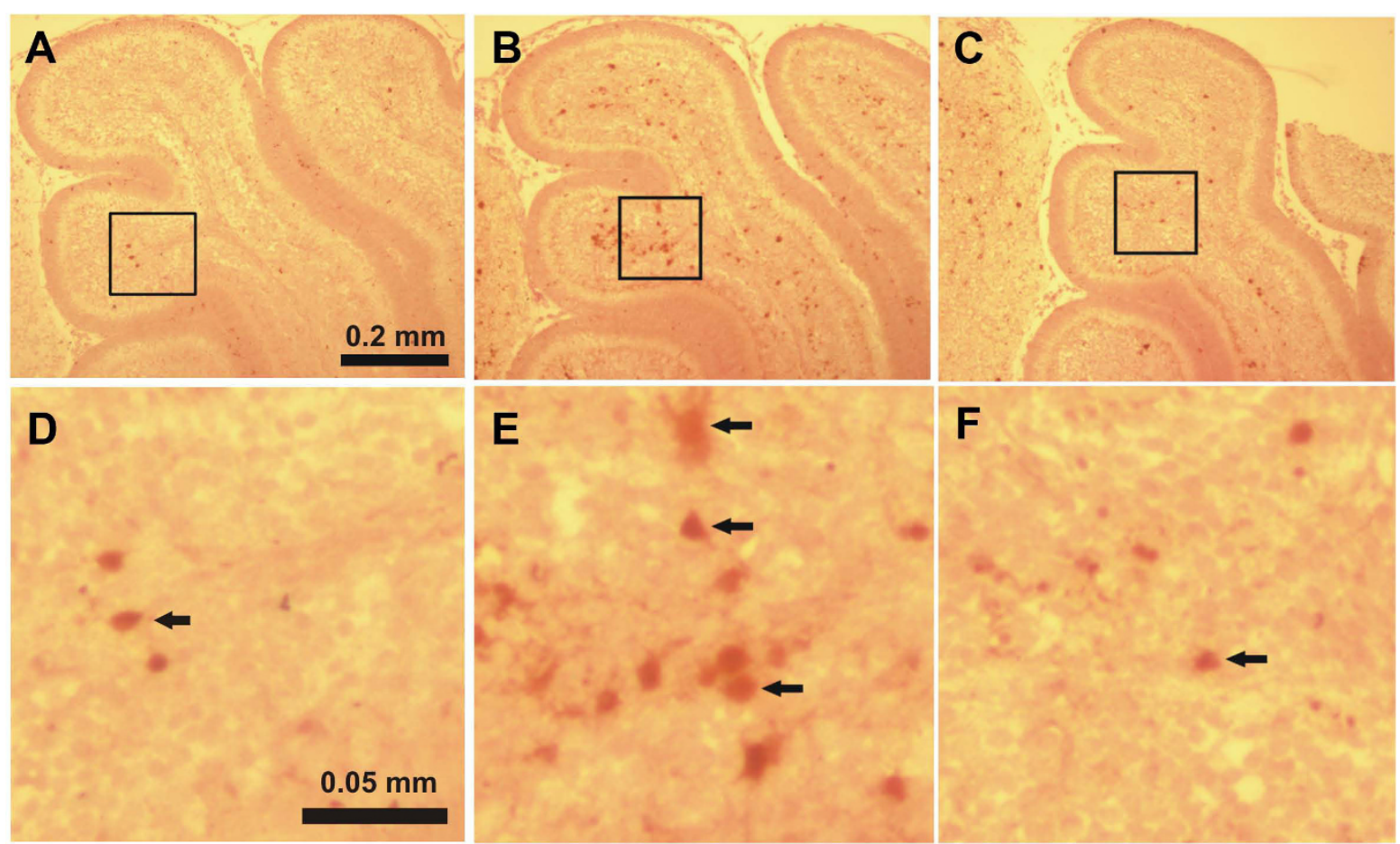

Figure 2 Immunostaining for activated caspase-3 in lobule IV-V of the cerebellum of 7-day-old mice 8 hours after the first ethanol injection A, D: control group, B, E: ethanol-treated group, C, F: ethanol+taurine-treated group. The activated caspase-3-immunoreactive cells in the IGL are indicated by black arrows. 


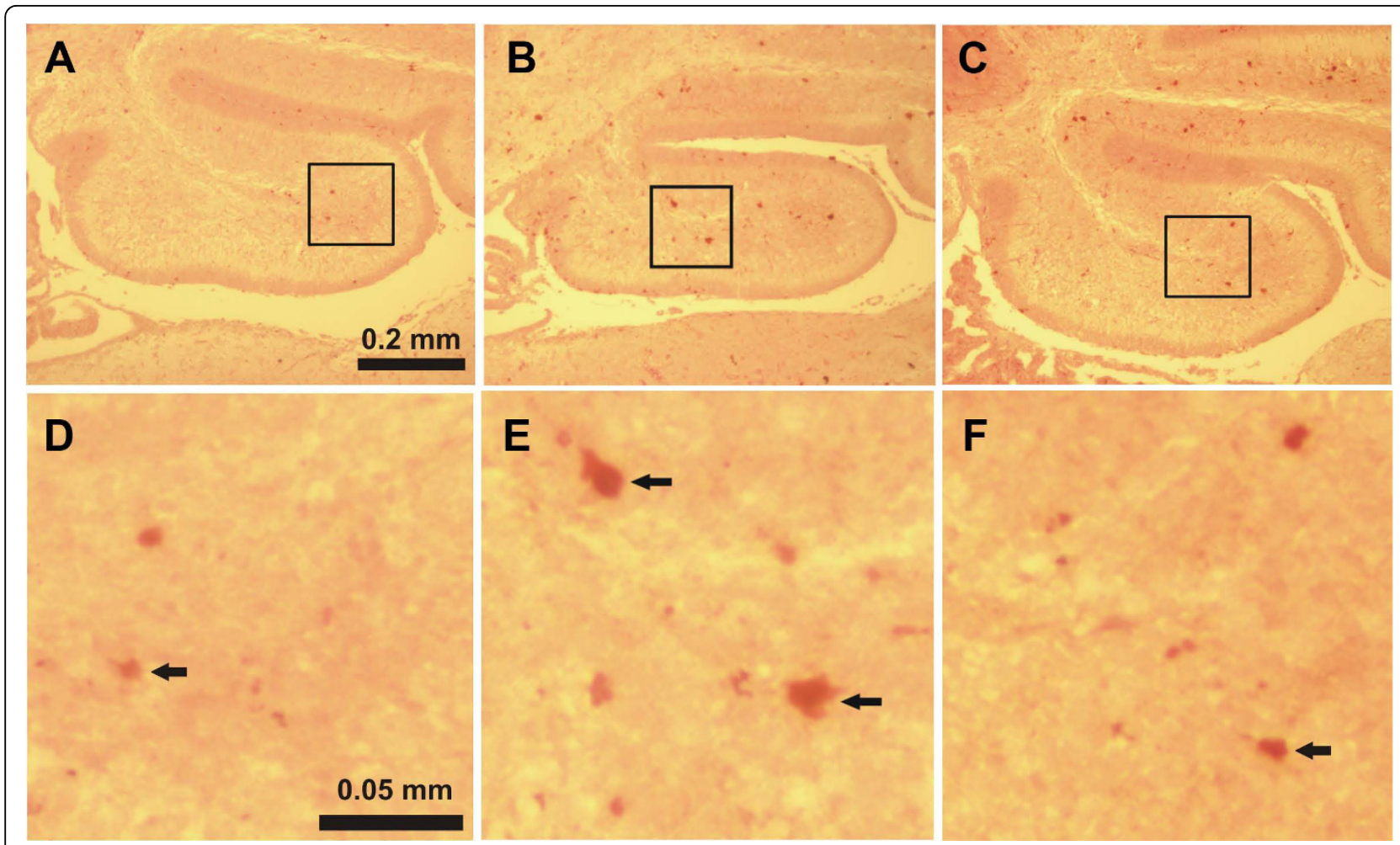

Figure 3 Immunostaining for activated caspase-3 in lobule $X$ of the cerebellum of 7-day-old mice 8 hours after the first ethanol injection A, D: control group, B, E: ethanol-treated group, C, F: ethanol+taurine-treated group. The activated caspase-3-immunoreactive cells in the $I G L$ are indicated by black arrows.
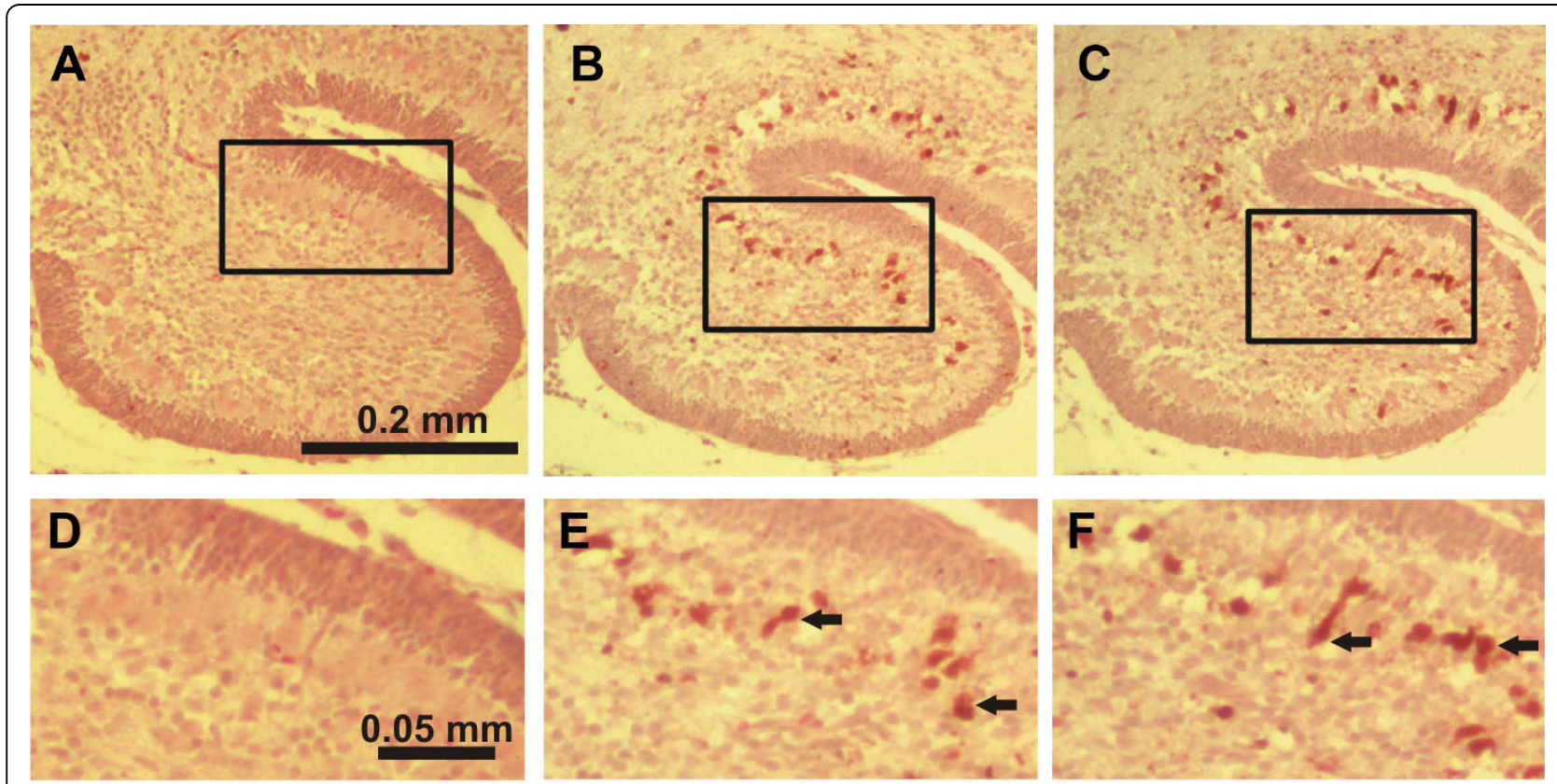

Figure 4 Immunostaining for activated caspase-3 in lobule $X$ of the cerebellum of 4-day-old mice 12 hours after the first ethanol injection A, D: control group, B, E: ethanol-treated group, C, F: ethanol+taurine-treated group. The activated caspase-3-immunoreactive Purkinje cells are indicated by black arrows. 

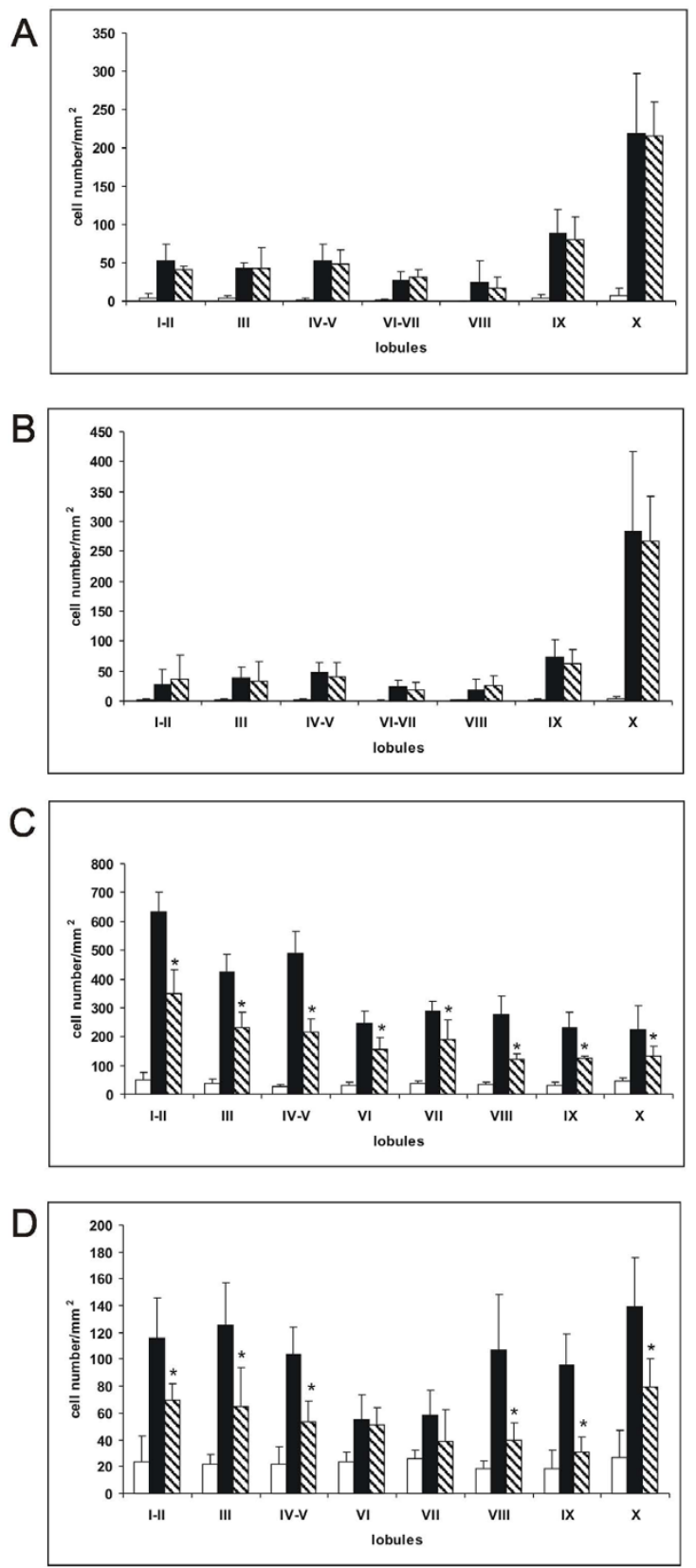

Figure 5 Effects of taurine on ethanol-induced apoptosis in the developing cerebellum (A) Number of activated caspase-3 immunoreactive Purkinje cells in the cerebellar lobules of 4-day-old mice in the control (open bars), ethanol-treated (filled bars) and ethanol +taurine-treated (hatched bars) mice. The results are given per $\mathrm{mm}^{2}$ with standard deviations. Number of animals in each group is 5 . Ethanol significantly $(P<0.01)$ increased the number of caspase-3 immunoreactive cells in all lobules. There were no significant differences between the ethanol and ethanol+taurine groups. (B) Number of apoptotic Purkinje cells (labeled by TUNEL assay) in the cerebellar lobules of 4-day-old mice in the control (open bars), ethanol-treated (filled bars) and ethanol+taurine-treated (hatched bars) mice. The results are given per $\mathrm{mm}^{2}$ with standard deviations. Number of animals in each group is 5 . Ethanol significantly $(P<0.01)$ increased the number of TUNEL-positive Purkinje cells in all lobules. There were no significant differences between the ethanol and ethanol+taurine groups. (C) Number of activated caspase-3immunoreactive cells in the IGL in the cerebellar lobules of 7-day-old mice in the control (open bars), ethanol-treated (filled bars) and ethanol +taurine-treated (hatched bars) mice. The results are given per $\mathrm{mm}^{2}$ with standard deviations. Number of animals in each group is 5 . Ethanol significantly $(\mathrm{P}<0.01)$ increased the number of caspase-3 immunoreactive cells in all lobules. The significance of differences between the ethanol and ethanol+taurine groups: ${ }^{*}<<0.05$.(D) The number of apoptotic cells (labeled by TUNEL assay) in the IGL in the cerebellar lobules of 7-day-old mice in the control (open bars), ethanol-treated (filled bars) and ethanol+taurine-treated (hatched bars) mice. The results are given per $\mathrm{mm}^{2}$ with standard deviation. Number of animals in each group is 5 . Ethanol significantly $(P<0.01)$ increased the number of TUNEL-positive cells in all lobules. The significance of differences between the ethanol and ethanol+taurine groups: ${ }^{*}<<0.05$. 
during normal development. The amount of cells undergoing physiological cell death in the Purkinje layer seems to be less than in the IGL and it was in accordance with our data on activated caspase-3 immunoreactivity.

Ethanol treatment significantly increased the number of cells with fragmented DNA labeled by the TUNEL assay in the Purkinje cell layer of P4 mice (Figure 5B). The largest number of TUNEL-positive Purkinje cells was found in lobules IX and X (Figure 6B, 6E), although in the other lobules studied the amount of TUNEL-positive Purkinje cells was also much greater than in the control group. At age P7, ethanol administration induced massive apoptosis in the IGL in all vermian lobules as indicated by the increased amount of TUNEL-positive cells (Figure 5D).

Taurine treatment did not change the amount of TUNEL-positive Purkinje cells on P4 in any lobule studied when compared to the pups treated only with ethanol (Figure 5B; Figure 6). The amount of TUNELpositive Purkinje cells remained much greater than in the saline-treated control group. In the ethanol+taurine group at age P7 the number of TUNEL-positive IGL cells was reduced in comparison to the ethanol group, the change being statistically significant in all other lobules except lobules VI and VII (Figure 5D). Although taurine treatment decreased the number of TUNEL-positive IGL cells induced by acute alcohol administration, the number of TUNEL-positive cells in the ethanol+taurine group remained much larger than in the control group. Taurine preservation of IGL cells from DNA fragmentation varied in the lobules from $40 \%$ (lobule I-II) to $68 \%$ (lobule IX).

\section{Dynamics of taurine blood concentration changes during the experiments}

We measured the taurine concentration in blood serum during the experiments from $4 \mathrm{~h}$ onwards after the first ethanol injection (1 hour after last taurine injection) at every hour for $12 \mathrm{~h}$ and then again at $24 \mathrm{~h}$ (Figure 7). In the saline-treated control group and in the ethanol group of P7 mice the taurine concentration remained the same at $4 \mathrm{~h}, 12 \mathrm{~h}$ and $24 \mathrm{~h}$. It was $1.00 \pm 0.42$ $\mathrm{mmol} / \mathrm{l}$ in the control group and $0.85 \pm 0.24 \mathrm{mmol} / \mathrm{l}$ in the ethanol group. Two subcutaneous injections of taurine each at the dose $1 \mathrm{~g} / \mathrm{kg}$ (one at $0 \mathrm{~h}$ and second at $4 \mathrm{~h}$ ) markedly increased the taurine level up to $13.36 \pm$ $2.73 \mathrm{mmol} / \mathrm{l}$ at $4 \mathrm{~h}$ after the first ethanol injection. For four hours $(4 \mathrm{~h}-7 \mathrm{~h})$ the concentration in the blood was maintained at about the same high level of $13.20 \pm 1.83$ $\mathrm{mmol} / \mathrm{l}$ and then it started to decline gradually and almost reached the control level by $12 \mathrm{~h}(1.59 \pm 0.83$ $\mathrm{mmol} / \mathrm{l})$.

\section{Discussion}

The central nervous system is extremely sensitive to alcohol during development and the periods of vulnerability are temporally well defined. The time frames of vulnerability are different for different neuronal populations. In the developing mouse cerebellum acute
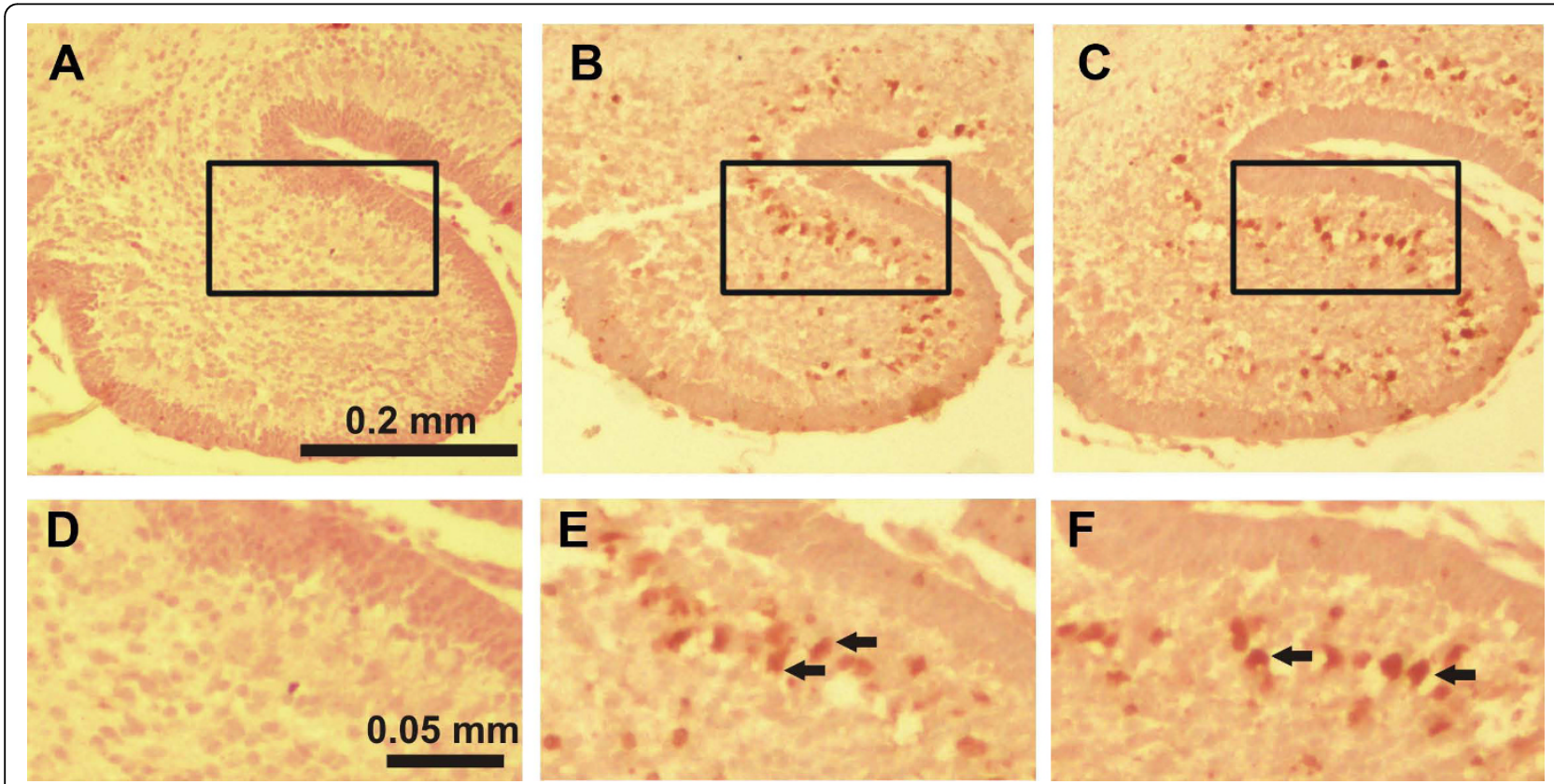

Figure 6 TUNEL staining in lobule $X$ of the cerebellum of 4-day-old mice 12 hours after the first ethanol injection $A$, D: control group, B, E: ethanol-treated group, C, F: ethanol+taurine-treated group. TUNEL-positive Purkinje cells are indicated by black arrows. 


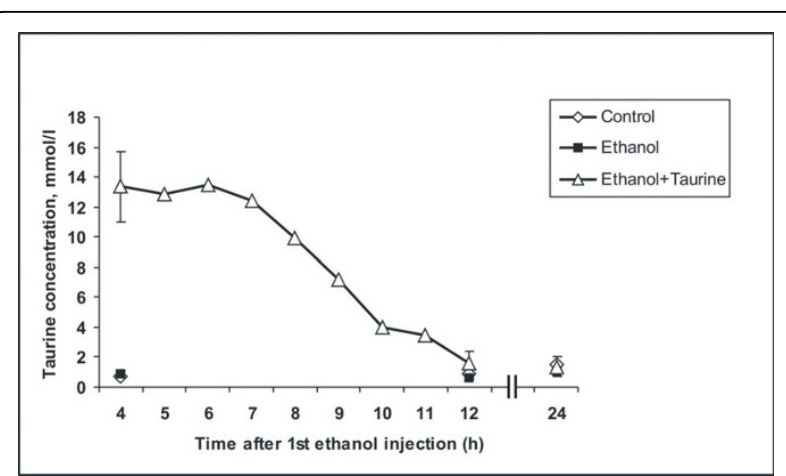

Figure 7 Changes in the taurine concentration in blood plasma during the experiment in 7-day-old mice Data are presented as mean values. Standard deviations are shown only for samples at 4 $h, 12 \mathrm{~h}$ and $24 \mathrm{~h}$ after the first ethanol injection.

alcohol intoxication thus induces massive neuronal death of Purkinje cells on P2-P6 and of cells in the IGL on P7-P9 [25]. In our experiments P4 and P7 mice pups were used to induce ethanol-induced degeneration of Purkinje and IGL cells, respectively. It is well established that alcohol induces neuronal death in the developing brain by apoptosis [11]. Apoptosis is a type of programmed cell death with specific morphologic features [28]. Immature neurons dying due to ethanol exposure, exhibit biochemical and ultrastructural features of apoptosis such as activation of caspase- 3 $[12,13]$, internucleosomal DNA fragmentation $[7,14]$, clumping of nuclear chromatin, formation of spherical chromatin masses and nuclear membrane fragmentation $[7,25,29]$.

Two major apoptotic pathways have been established: the death-receptor-mediated and the mitochondrialmediated apoptosis [28], also known as the "extrinsic" and as "intrinsic" apoptotic pathways, respectively [30]. In both pathways, the caspases, a family of cysteinedependent aspartate-directed proteases, play an important role in initiation, signal transduction and execution of apoptosis $[31,32]$. The extrinsic pathway is triggered by activation of death receptors localized at the cell membrane surface and it induces caspase- 8 processing. The activated caspase- 8 can directly or indirectly activate effector caspases such as caspases-3, -6 and -7 . In the intrinsic pathway, many factors such as nitric oxide, oxidants and proapoptotic proteins, e.g. Bax, increase mitochondrial membrane permeability and release cytochrome $\mathrm{C}$ into the cytoplasm. Cytochrome $\mathrm{C}$ binds to Apaf- 1 and procaspase-9, forming an apoptosome, leading to caspase-9 activation [33]. The active caspase-9 cleaves and activates effector caspases, including caspase-3. The activated effector caspases cleave many structural and functional proteins and activate DNase which destroys chromosomes and leads to cell death
[31,32]. As shown with Bax-knock-out mice, ethanolinduced apoptosis in the developing brain is a Baxdependent process which requires translocation of the Bax protein from the cytosol to mitochondria, disruption of mitochondrial membranes, release of cytochrome $\mathrm{C}$ and activation of caspase-3. All these events and also the absence of capase- 8 activation indicate that alcohol induces apoptosis in the developing brain via intrinsic (mitochondrial-mediated) apoptotic pathways [34,35].

In the present experiments we demonstrate that acute ethanol administration to $\mathrm{P} 4$ mice induces activation of caspase- 3 and DNA fragmentation in Purkinje neurons in all vermian lobules studied. This finding is in concert with the results of other authors working with mice [25] and rats [36]. Ethanol administration to mice pups at age P7 markedly enhanced the number of activated caspase-3-IR and TUNEL-positive cells in the IGL but did not markedly affect the Purkinje cells. This time difference in alcohol sensitivity of different types of neurons is not surprising, being already shown in other studies [25].

The presence of taurine at high concentrations during the early ontogenesis is essential for normal development [37]. Taurine has been tested in treatment of many diseases, including cardiovascular disorders, epilepsy, macular degeneration, hepatic disorders, cystic fibrosis, Alzheimer's disease and alcoholism [38]. It also interacts with the effects of ethanol [39]. For instance, it modulates ethanol-stimulated locomotion [40] and prolongs ethanol-induced sedation when given intracerebroventricularly to mice $[41,42]$. Furthermore, ethanol administration elicits an increase in extracellular taurine in the rat cerebral cortex and hippocampus [43]. However, many findings on taurine and ethanol interactions have been contradictory. For instance, in behavioural studies taurine pretreatment has reduced the duration of ethanol-induced sleep-time and attenuated the loss of righting reflex $[44,45]$, not altered the ethanol-induced loss of righting reflex [46] or even enhanced it [41]. It seems that interactions of taurine and ethanol in the brain depend largely on the experimental set-up and the doses of ethanol and taurine administered [19].

Mounting recent evidence indicates that taurine is involved in apoptosis regulation and protects many cell types under different pathological conditions such as ischemia [22,23], high glucose level [47], oxidative stress [48], and ethanol intoxication [49]. In adult rats intraperitoneal taurine injections markedly increase the taurine concentration in blood plasma and brain microdialysates in a dose-dependent manner [50]. After a single injection of $1 \mathrm{~g} / \mathrm{kg}$ taurine the maximal plasma and brain concentrations are reached within $20 \mathrm{~min}$ and they remain significantly higher than in controls for 3.5$4 \mathrm{~h}$. The present two taurine injections at the dose of 
$1 \mathrm{~g} / \mathrm{kg}$ each with the 4-h interval keep the level of taurine high for a more prolonged time. The present finding that in this manner taurine attenuated apoptosis in the IGL is in accordance with our previous study [49].

However, in P4 mice we got unexpected results that taurine had no effect on the ethanol-induced activation of caspase- 3 and apoptosis in Purkinje cells. Taurine can be involved in apoptosis regulation by several ways. First of all, taurine decreases intracellular free $\mathrm{Ca}^{2+}$ by inhibiting all types of voltage-gated calcium channels and the N-methyl-D-aspartate (NMDA) receptor-gated calcium channel $[24,51]$ and by increasing $\mathrm{Ca}^{2+}$ buffering in mitochondria [52]. It prevents in this manner activation of calpain (calcium-dependent protease) and protects mitochondrial membranes from disruption [24]. Taurine can also protect cells acting as antioxidants [15], scavenging at its different physiological concentrations many reactive oxygen and nitrogen species [53], although ethanol administration to neonatal rats may not induce oxidative stress to cerebellar granular neurons [54]. For cell survival a balance between the proapoptotic protein Bax and the antiapoptotic protein $\mathrm{Bcl}-2$ is very important. A decrease in the Bcl-2 level in cells leads to translocation of Bax to mitochondria, disruption of their membranes and a release of cytohrome $\mathrm{C}$ from mitochondria to the cytosol [55]. Taurine application can restore the pool of $\mathrm{Bcl}-2$ and protect cells against apoptosis [24]. Since ethanol-induced apoptosis is a Bax-dependent process [34], we suggest that restoration of the Bcl-2 level was one possible mechanism of apoptosis prevention in our experiments. Taurine may also be able to rescue cells from apoptosis after the release of cytochrome $\mathrm{C}$ from mitochondria. In ischemic cardiomyocytes taurine suppresses the formation of the Apaf-1/caspase- 9 apoptosome, prevents caspase- 9 activation and thereby preserves cells from apoptosis [22]. All these mechanisms may explain why taurine protects IGL neurons from ethanol-induced apoptosis in P7 mice.

It also seems important to consider another possibility of taurine protection against the adverse effect of ethanol, which is not directly related to apoptosis. Alcohol alters physical properties of membrane lipids, changing membrane fluidity and affecting physiologically important membrane enzymes, for instance, $\mathrm{Na}^{+} / \mathrm{K}^{+}$-ATPase activity [56-59]. The effects of alcohol on biological membranes depend on the duration of its administration. Acute ethanol administration increases the membrane fluidity [60-62], whereas chronic alcohol intake decreases the fluidity of membranes $[60,63,64]$, which become more tolerant to the disordering effect of ethanol $[60,63]$. Acute ethanol exposure also decreases $\mathrm{Na}^{+} /$ $\mathrm{K}^{+}$-ATPase activity in the cerebral cortex and brain stem [65] and kidneys of adult rats [66].
The experimental data on the chronic alcohol effect on $\mathrm{Na}^{+} / \mathrm{K}^{+}$-ATPase activity seem more contradictory. For instance, chronic alcohol intake has enhanced $\mathrm{Na}^{+} /$ $\mathrm{K}^{+}$-ATPase activity in rat erythrocyte membranes [58] and in the brain [67]. However, in other studies the activity of $\mathrm{Na}^{+} / \mathrm{K}^{+}$-ATPase was significantly decreased after chronic alcohol consumption in human erythrocyte membranes [59] and in the brain and cerebellum of rat offspring upon chronic alcohol exposure in utero [68]. Taurine also acts as a membrane stabilizer and restores the depletion of $\mathrm{Na}^{+} / \mathrm{K}^{+}$-ATPase activity due to ozone exposure and prevents the depletion of the enzyme activity due to cholesterol enrichment [69]. Furthermore, taurine decreases the fluidity of biological membranes when coadministrated with calcium [70]. It seems thus possible that taurine in addition to its antiapoptotic actions can reduce the adverse effects of acute ethanol administration acting as membrane stabilizer by the decreasing membrane fluidity and restoring the $\mathrm{Na}^{+} / \mathrm{K}^{+}$-ATPase activity.

Hovewer, the above considerations do not explain why taurine did not affect apoptosis of Purkinje cells on P4. An explanation may be the different functional properties of the neurons studied. The granular neurons in the IGL are glutamatergic and the Purkinje cells GABAergic. Ethanol can induce apoptosis in the developing brain by dual mechanisms, by either blocking NMDA receptors and or by excessively activating $\mathrm{GABA}_{\mathrm{A}}$ receptors [7]. Taurine itself is an inhibitory amino acid which mimics GABA actions $[71,72]$. On the other hand, taurine inhibits the glutamate-induced $\mathrm{Ca}^{2+}$ elevation [73]. Another simple explanation for different effects of taurine on ethanol-induced apoptosis in Purkinje and IGL cells may be the difference in time when the neuronal populations were studied. We studied P4 mice at 12 hours and P7 mice at 8 hours after the first ethanol administration. Taurine is readily excreted in urine and its plasma concentration decreases during the experiments. At 8 hours the concentration was still relatively high but at 12 hours almost at the control level; it was not high enough to protect Purkinje cells.

\section{Conclusions}

We show that acute alcohol administration induces apoptosis in Purkinje cells and in cells in the internal granule cell layer (IGL) of the cerebellum. The time frame of sensitivity to ethanol administration is different for Purkinje and IGL cells. Taurine application was neuroprotective against ethanol-induced apoptosis in cells in the IGL. Prevention of caspase-3 activation and DNA fragmentation by taurine in IGL cells is likely to be due to one or several of the following mechanisms, including the restoration of the pool of Bcl-2, regulation of intracellular $\mathrm{Ca}^{2+}$ and inhibition of caspase- 9 activation. The 
failure of prevention of ethanol-induced apoptosis by taurine in Purkinje cells may result from the different functional properties of the neurons studied. GABAergic Purkinje cells are inhibitory and glutamatergic granular cells excitatory. The decrease in the taurine level during the experiments may also have an influence since Purkinje cells were studied after a longer interval than IGL cells.

\section{List of abbreviations used}

HPLC: high-performance liquid chromatography; P4: postnatal day 4; P7: postnatal day 7; TUNEL: terminal deoxynucleotidyl transferase-mediated dUTP nick end-labeling; OPA: o-phthaldialdehyde; ANOVA: analysis of variance; IGL: internal granular cell layer; IR: immunoreactive; NMDA: $\mathrm{N}$-methyl-D-aspartate.

\section{Acknowledgements}

The authors are deeply grateful to Mrs. Raija Repo, Mrs. Irma Rantamaa and Mrs. Ulla M. Jukarainen for excellent technical assistance. This study was supported by the competitive research funding of the Pirkanmaa Hospital District and the Finnish Foundation for Alcohol Studies.

This article has been published as part of Journal of Biomedical Science Volume 17 Supplement 1, 2010: Proceedings of the 17th International Meeting of Taurine. The full contents of the supplement are available online at http://www.jbiomedsci.com/supplements/17/S1.

\section{Author details}

'Brain Research Center, University of Tampere Medical School, Tampere, Finland. ${ }^{2}$ Laboratory of Comparative Somnology and Neuroendocrinology, Sechenov Institute of Evolutionary Physiology and Biochemistry, St.Petersburg, Russia. ${ }^{3}$ Department of Developmental Biology, University of Tampere Medical School and Department of Pathology, Tampere University Hospital, Tampere, Finland. ${ }^{4}$ Department of Paediatrics, Tampere University Hospital, Tampere, Finland.

\section{Authors' contributions}

AGT did all laboratory work and drafted the manuscript, EYT performed the statistical analyses and prepared illustrations, IMP participated in invention of the idea and design of the study, MPH was the expert in immunohistochemistry and PS and SSO acted supervisors and composed the final version of this article. All authors read and approved the manuscript.

\section{Competing interests}

The authors declare that they have no competing interests.

Published: 24 August 2010

\section{References}

1. Di Castelnuovo A, Costanzo S, Donati MB, lacoviello L, de Gaetano G: Prevention of cardiovascular risk by moderate alcohol consumption: epidemiologic evidence and plausible mechanisms. Intern Emerg Med 2010, [Epub ahead of print].

2. Pfefferbaum A, Sullivan EV, Mathalon DH, Lim KO: Frontal lobe volume loss observed with magnetic resonance imaging in older chronic alcoholics. Alcohol Clin Exp Res 1997, 21:521-529.

3. Harding AJ, Halliday GM, NG JLF, Harper CG, Kril JJ: Loss of vasopressinimmunoreactive neurons in alcoholics is dose-related and timedependent. Neuroscience 1996, 72:699-708.

4. Mochizuki H, Masaki T, Matsushita S, Ugawa Y, Kamakura K, Arai H, Motoyoshi K, Higuchi S: Cognitive impairment and diffuse white matter atrophy in alcoholics. Clin Neurophysiol 2005, 116:223-228.

5. Farber NB, Heinkel C, Dribben WH, Nemmers B, Jiang X: In the adult CNS, ethanol prevents rather than produces NMDA antagonist-induced neurotoxicity. Brain Res 2004, 1028:66-74.
6. Young C, Olney JW: Neuroapoptosis in the infant mouse brain triggered by a transient small increase in blood alcohol concentration. Neurobiol Dis 2006, 22:548-554.

7. Ikonomidou C, Bittigau P, Ishimaru MJ, Wozniak DF, Koch C, Genz K, Price MT, Stefovska V, Hörster F, Tenkova T, Dikranian K, Olney JW: Ethanolinduced apoptotic neurodegeneration and fetal alcohol syndrome. Science 2000, 287:1056-1060.

8. Warren KR, Bast RJ: Alcohol-related birth defects: an update. Public Health Rep 1988, 103:638-642.

9. Dalen K, Bruaroy S, Wentzel-Larsen T, Laegreid LM: Cognitive functioning in children prenatally exposed to alcohol and psychotropic drugs. Neuropediatrics 2009, 40:162-167.

10. Rice $D$, Barone $S \mathrm{Jr}$ : Critical periods of vulnerability for the developing nervous system: evidence from humans and animal models. Environ Health Perspect 2000, 108:511-533.

11. Olney JW, Ishimaru MJ, Bittigau P, Ikonomidou C: Ethanol-induced apoptotic neurodegeneration in the developing brain. Apoptosis 2000, 5:515-521.

12. Olney JW, Tenkova T, Dikranian K, Muglia LJ, Jermakowicz WJ, D'Sa C, Roth KA: Ethanol-induced caspase-3 activation in the in vivo developing mouse brain. Neurobiol Dis 2002, 9:205-219.

13. Olney JW, Tenkova T, Dikranian K, Qin YQ, Labruyere J, Ikonomidou C: Ethanol-induced apoptotic neurodegeneration in the developing C57BL/ 6 mouse brain. Brain Res Dev Brain Res 2002, 133:115-126.

14. Kumral A, Tugyan K, Gonenc S, Genc K, Genc S, Sonmez U, Yilmaz O, Duman N, Uysal N, Ozkan H: Protective effects of erythropoietin against ethanol-induced apoptotic neurodegeneration and oxidative stress in the developing C57BL/6 mouse brain. Brain Res Dev Brain Res 2005, 160:146-156.

15. Lourenco R, Camilo ME: Taurine: a conditionally essential amino acid in humans? An overview in health and disease. Nutr Hosp 2002, 17:262-270.

16. Huxtable RJ: Physiological actions of taurine. Physiol Rev 1992, 72:101-163.

17. Saransaari P, Oja SS: Taurine and neural cell damage. Amino Acids 2000, 19:509-526.

18. Anderzhanova E, Saransaari P, Oja SS: Neuroprotective mechanisms of taurine in vivo. Adv Exp Med Biol 2006, 583:377-387.

19. Oja SS, Saransaari P: Taurine. Handbook of Neurochemistry and Molecular Neurobiology. Amino Acids and Peptides in the Nervous System New York, Springer Oja SS, Schousboe A, Saransaari P, 3rd 2007, 6:156-206.

20. Oja SS, Saransaari P: Pharmacology of taurine. Proc West Pharmacol Soc 2007, 50:8-15.

21. Wang JH, Redmond HP, Watson RW, Condron C, Bouchier-Hayes D: The beneficial effect of taurine on the prevention of human endothelial cell death. Shock 1996, 6:331-338.

22. Takatani T, Takahashi K, Uozumi Y, Shikata E, Yamamoto Y, Ito T, Matsuda T, Schaffer SW, Fujio Y, Azuma J: Taurine inhibits apoptosis by preventing formation of the Apaf-1/caspase-9 apoptosome. Am J Physiol Cell Physiol 2004, 287:C949-C953.

23. Taranukhin A, Taranukhina E, Saransaari P, Djatchkova I, Pelto-Huikko M, Oja SS: Taurine reduces caspase-8 and caspase- 9 expression induced by ischemia in the mouse hypothalamic nuclei. Amino Acids 2008, 34:169-174.

24. Wu JY, Wu H, Jin Y, Wei J, Sha D, Prentice H, Lee HH, Lin CH, Lee YH, Yang LL: Mechanism of neuroprotective function of taurine. Adv Exp Med Biol 2009, 643:169-179.

25. Dikranian $\mathrm{K}$, Qin $Y Q$, Labruyere J, Nemmers B, Olney JW: Ethanol-induced neuroapoptosis in the developing rodent cerebellum and related brain stem structures. Brain Res Dev Brain Res 2005, 155:1-13.

26. Migheli A, Atanasio A, Schiffer D: Ultrastructural detection of DNA strand breaks in apoptotic neural cells by in situ endlabelling techniques. $J$ Pathol 1995, 176:27-35.

27. Wijsman JH, Jonker RR, Keijzer R, van de Velde CJ, Cornelisse CJ, van Dierendonck JH: A new method to detect apoptosis in paraffin sections, ISEL of fragmented DNA. J Histochem Cytochem 1993, 41:7-12.

28. Hotchkiss RS, Strasser A, McDunn JE, Swanson PE: Cell death. New Engl J Med 2009, 361:1570-1583.

29. Dikranian K, Ishimaru MJ, Tenkova T, Labruyere J, Qin YQ, Ikonomidou C, Olney JW: Apoptosis in the in vivo mammalian forebrain. Neurobiol Dis 2001, 8:359-379. 
30. Boatright KM, Salvesen GS: Mechanisms of caspase activation. Curr Opin Cell Biol 2003, 15:725-731

31. Budihardjo I, Oliver H, Lutter M: Biochemical pathways of caspase activation during apoptosis. Annu Rev Cell Dev Biol 1999, 15:269-290.

32. Earnshaw WC, Martins LM, Kaufmann SH: Mammalian caspases: structure, activation, substrates, and functions during apoptosis. Annu Rev Biochem 1999, 68:383-424.

33. Purring-Koch C, McLendon G: Cytochrome $c$ binding to Apaf-1: the effects of dATP and ionic strength. Proc Natl Acad Sci USA 2000, 97:11928-11931.

34. Young C, Klocke BJ, Tenkova T, Choi J, Labruyere J, Qin YQ, Holtzman DM, Roth KA, Olney JW: Ethanol-induced neuronal apoptosis in vivo requires BAX in the developing mouse brain. Cell Death Differ 2003, 10:1148-1155.

35. Nowoslawski L, Klocke BJ, Roth KA: Molecular regulation of acute ethanolinduced neuron apoptosis. J Neuropathol Exp Neurol 2005, 64:490-497.

36. Light KE, Belcher SM, Pierce DR: Time course and manner of Purkinje neuron death following a single ethanol exposure on postnatal day 4 in the developing rat. Neuroscience 2002, 114:327-237.

37. Sturman JA: Taurine in development. Physiol Rev 1993, 73:119-147.

38. Birdsall TC: Therapeutic application of taurine. Altern Med Rev 1998, 3:128-136

39. Olive MF: Interactions between taurine and ethanol in the central nervous system. Amino Acids 2002, 23:345-357.

40. Aragón CM, Trudeau LE, Amit Z: Effect of taurine on ethanol-induced changes in open-field locomotor activity. Psychopharmacology 1992, 107:337-340.

41. Ferko AP: Ethanol-induced sleep time: interaction with taurine and a taurine antagonist. Pharmacol Biochem Behav 1987, 27:235-238.

42. Ferko AP, Babyock E: Effect of taurine on ethanol-induced sleep in mice genetically bred for differences in ethanol sensitivity. Pharmacol Biochem Behav 1988, 31:667-673.

43. Dachhour A, De Witte P: Ethanol and amino acids in the central nervous system. Assessment of the pharmacological actions of acamprosate. Prog Neurobiol 2000, 60:343-362.

44. lida S, Hikichi M: Effect of taurine on ethanol-induced sleeping time in mice. J Stud Alcohol 1976, 37:19-26.

45. Boggan WO, Medberry C, Hopkins DH: Effect of taurine on some pharmacological properties of ethanol. Pharmacol Biochem Behav 1978, 9:469-472

46. Ginsburg BC, Lamb RJ: Taurine and ethanol interactions: behavioral effects in mice. Eur J Pharmacol 2008, 578:228-237.

47. Ulrich-Merzenich $G$, Zeitler $H$, Vetter $H$, Bhonde RR: Protective effects of taurine on endothelial cells impaired by high glucose and oxidized low density lipoproteins. Eur J Nutr 2007, 46:431-438.

48. Das J, Ghosh J, Manna P, Sinha M, Sil PC: Taurine protects rat testes against $\mathrm{NaAsO}_{2}$-induced oxidative stress and apoptosis via mitochondrial dependent and independent pathways. Toxicol Lett 2009, 187:201-210

49. Taranukhin A, Taranukhina E, Saransaari P, Djatchkova I, Pelto-Huikko M, Oja SS: Taurine protects immature cerebellar granule neurons against acute alcohol administration. Adv Exp Med Biol 2009, 643:159-167.

50. Lallemand F, De Witte P: Taurine concentration in the brain and in the plasma following intraperitoneal injections. Amino Acids 2004, 26:111-116.

51. Wu H, Jin $Y$, Wei J, Jin H, Sha D, Wu J-Y: Mode of action of taurine as a neuroprotector. Brain Res 2005, 1038:123-131.

52. El Idrissi A: Taurine increases mitochondrial buffering of calcium: role in neuroprotection. Amino Acids 2008, 34:321-328.

53. Oliveira MWS, Minotto JB, de Oliveira MR, Zanotto-Filho A, Behr GA, Rocha RF, Moreira JCF, Klamt F: Scavenging and antioxidant potential of physiological taurine concentrations against different reactive oxygen/ nitrogen species. Pharmacol Rep 2010, 62:185-193.

54. Kane CJM, Chang JY, Roberson PK, Garg TK, Han L: Ethanol exposure of neonatal rats does not increase biomarkers of oxidative stress in isolated cerebellar granule neurons. Alcohol 2008, 42:29-36.

55. Hagberg $\mathrm{H}$, Mallard $\mathrm{C}$, Rousset $\mathrm{Cl}$, Xiaoyang Wang: Apoptotic mechanisms in the immature brain: involvement of mitochondria. J Child Neurol 2009, 24:1141-1146.

56. Harris RA, Hitzemann RJ: Membrane fluidity and alcohol actions. Curr Alcohol 1981, 8:379-404.

57. Swann AC: Membrane effects of ethanol in excitable cells. Rev Clin Basic Pharm 1987, 6:213-248.
58. Sadrzadeh SM, Price P, Nanji AA: Ethanol-induced changes in membrane ATPases: inhibition by iron chelation. Biochem Pharmacol 1994, 47:745-747.

59. Maturu $P$, Vaddi DR, Pannuru $P$, Nallanchakravarthula V: Alterations in erythrocyte membrane fluidity and $\mathrm{Na}^{+} / \mathrm{K}^{+}$-ATPase activity in chronic alcoholics. Mol Cell Biochem 2010, 339:35-42.

60. Rubin $\mathrm{E}$, Rottenberg $\mathrm{H}$ : Ethanol-induced injury and adaptation in biological membranes. Fed Proc 1982, 41:2465-2471.

61. Bjorkman DJ, Jessop LD: Effects of acute and chronic ethanol exposure on intestinal microvillus membrane lipid composition and fluidity. Alcohol Clin Exp Res 1994, 18:560-565.

62. Gutiérrez-Ruiz MC, Gómez JL, Souza V, Bucio L: Chronic and acute ethanol treatment modifies fluidity and composition in plasma membranes of a human hepatic cell line (WRL-68). Cell Biol Toxicol 1995, 11:69-78.

63. Goldstein DB, Chin JH: Interaction of ethanol with biological membranes. Fed Proc 1981, 40:2073-2076.

64. Gossai D, Lau-Cam CA: The effects of taurine, hypotaurine, and taurine homologs on erythrocyte morphology, membrane fluidity and cytoskeletal spectrin alterations due to diabetes, alcoholism and diabetes-alcoholism in the rat. Adv Exp Med Biol 2009, 643:369-379.

65. Rao PA, Kumari CL, Sadasivudu B: Acute and short term effects of ethanol on membrane enzymes in rat brain. Neurochem Res 1985, 10:1577-1585.

66. Rodrigo R, Thielemann L, Orellana M: Acute and chronic effect of ethanol on $\mathrm{Na}^{+} / \mathrm{K}^{+}$-ATPase activity and cyclic AMP response to vasopressin in rat papillary collecting duct cells. Gen Pharmacol 1998, 30:663-667.

67. Guerri C, Wallace R, Grisolia S: The influence of prolonged ethanol intake on the levels and turnover of alcohol and aldehyde dehydrogenases and of brain $\mathrm{Na}^{+} / \mathrm{K}^{+}$-ATPase of rats. Eur J Biochem 1978, 86:581-587.

68. Rudeen PK, Guerri C: The effects of alcohol exposure in utero on acetylcholinesterase, $\mathrm{Na}^{+} / \mathrm{K}^{+}$-ATPase and $\mathrm{Ca}^{2+}$-ATPase activities in six regions of rat brain. Alcohol Alcohol 1985, 20:417-425.

69. Qi B, Yamagami T, Naruse Y, Sokejima S, Kagamimori S: Effects of taurine on depletion of erythrocyte membrane $\mathrm{Na}^{+} / \mathrm{K}^{+}$-ATPase activity due to ozone exposure or cholesterol enrichment. J Nutr Sci Vitaminol (Tokyo) 1995, 41:627-634.

70. Nakashima T, Shima T, Sakai M, Yama H, Mitsuyoshi H, Inaba K, Matsumoto N, Sakamoto Y, Kashima K, Nishikawa H: Evidence of a direct action of taurine and calcium on biological membranes. A combined study of 31P-nuclear magnetic resonance and electron spin resonance. Biochem Pharmacol 1996, 52:173-176.

71. Oja SS, Kontro P: Taurine. Handbook of Neurochemistry New York, Plenum PressLajtha A. , 2nd 1983, 3:501-533.

72. Saransaari P, Oja SS: Taurine in neurotransmission. Handbook of Neurochemistry and Molecular Neurobiology. Neurotransmitter Systems New York, SpringerVizi ES. , 3rd 2008, 2:325-342.

73. Chen WQ, Jin H, Nguyen M, Carr J, Lee YJ, Hsu CC, Faiman MD, Schloss JV, Wu JY: Role of taurine in regulation of intracellular calcium level and neuroprotective function in cultured neurons. J Neurosci Res 2001, 66:612-619.

doi:10.1186/1423-0127-17-S1-S12

Cite this article as: Taranukhin et al:: Neuroprotection by taurine in ethanol-induced apoptosis in the developing cerebellum. Journal of Biomedical Science 2010 17(Suppl 1):S12.

\section{Submit your next manuscript to BioMed Central and take full advantage of:}

- Convenient online submission

- Thorough peer review

- No space constraints or color figure charges

- Immediate publication on acceptance

- Inclusion in PubMed, CAS, Scopus and Google Scholar

- Research which is freely available for redistribution 